\title{
Testicular Development in Growth-Retarded Mice
}

\author{
Kenichi KOBAYASHI ${ }^{1)}$, Hisayo KUBOTA ${ }^{1)}$, and Junzo SAEGUSA ${ }^{1,2)}$ \\ 1)National Institute of Occupational Safety and Health, 6-21-1 Nagao, Tama-ku, Kawasaki, \\ Kanagawa 214-8585, and ${ }^{2}$ Okinawa Institute of Science and Technology, \\ 12-22 Suzaki, Uruma, Okinawa 904-2234, Japan
}

\begin{abstract}
To assess delayed fertility in male growth-retarded (grt) mice with congenital primary hypothyroidism, their testes were chronologically examined. The testicular weight in grt mice was significantly lower than age-matched normal mice until 8 weeks but was comparable at 13 and 26 weeks. While normal mice had mature sperm cells in both testes and epididymides at 5 weeks, age-matched grt mice did not. The size of the seminiferous tubules in testes of grt mice was smaller than that of normal mice before 13 weeks but was comparable at 26 weeks. These findings suggest that male grt mice might need more than 13 weeks to develop mature testes.
\end{abstract}

Key words: growth-retarded mouse, hypothyroid, testis

The growth-retarded ( $g r t)$ mouse was first reported as a mutant spontaneously derived from phenotypically normal siblings of the Snell's dwarf mouse (DW/J strain) with characteristic growth pause followed by delayed onset of pubertal growth in contrast to $d w$ mice [15]. In grt mice, plasma concentrations of thyroxine are significantly lower, whereas levels of thyroid-stimulating hormone (TSH) are greatly elevated [12, 15]. Our previous reports suggested that TSH can bind to its receptor in the grt thyroid gland, but is incapable of activating the second messenger signaling pathway $[9$, 10]. A mapping study indicated that the grt locus is located on mouse chromosome 5 and a mutation in the TSH receptor gene is unlikely to be responsible for the grt genotype [1].

We noticed that male grt mice are infertile at the young adult stage ( 13 weeks), but their fertility is partially restored after 26 weeks [8]. To understand the delayed maturity of testes in grt mice, we compared testicular development with that of phenotypically normal littermates.

A colony of grt mice was originally maintained at the animal facility at Saitama University (Saitama, Japan) under conventional conditions. An SPF colony of grt mice was established at Japan Laboratory Animals, Inc. (Tokyo, Japan) and then, they were introduced to our animal facility. The mice were kept in a semibarrier system with a controlled environment (temperature: $23 \pm 2^{\circ} \mathrm{C}$; humidity: $55 \pm 10 \%$; lighting: 12-h light/dark cycle) throughout the study. A standard laboratory diet (CE-2, CLEA Japan Inc., Tokyo, Japan) and tap water were available ad libitum. Normal phenotype $(+/+$ or $+/ g r t)$ and growth-retarded $($ grt $/$ $g r t)$ male mice were obtained by mating wild $(+/+)$ or heterozygous $(+/ g r t)$ female mice with grt male siblings [9]. Normal and grt mice were distinguished on 
the basis of their body weights as described elsewhere [15]. All studies were performed in accordance with the "institutional guidelines for animal care and use" of the National Institute of Occupational Safety and Health (Kawasaki, Japan).

After euthanasia, testes and epididymides were carefully isolated from 5-, 8-, 13- and 26-week-old normal and $g r t$ male mice. The tissues were fixed in phosphate-buffered formaldehyde solution for at least $24 \mathrm{~h}$ and then weighed. The tissues were embedded in paraffin and sections cut at $3 \mu \mathrm{m}$ thickness were stained with hematoxylin and eosin. Morphometric analysis of seminiferous tubules [6] was performed with modifications as follows. Briefly, the transverse area and the mean diameter $[($ maximal + minimal diameter $/ 2)]$ of 50 seminiferous tubules of testes from normal and grt mice from bilateral testes were measured per animal. Histological analyses were performed using the IPAP WIN (Sumika Technoservice Corp., Hyogo, Japan). The number of Leydig cells of each area corresponding to a microscopic field of $0.36 \mathrm{~mm}^{2}$ was counted. Values were expressed as the mean \pm SEM from 3-5 mice in each group. The statistical significance $(P<0.05)$ of differences was determined using Student's or Welch's $t$-test.

Body weights of grt mice were significantly slighter than normal mice until 26 weeks of age (Fig. 1A). In grt mice, testicular weight was significantly slighter than normal mice until 8 weeks of age but was similar at 13 and 26 weeks (Fig. 1B). The diameter and area of seminiferous tubules in grt mice were significantly less than those of normal mice at approximately 13 weeks of age, but were comparable at 26 weeks (Figs. 2 and 3). Mature sperm cells were seen in the testes and epididymides in normal mice at 5 weeks of age (Fig. 4A and 4C), but any sperms could not be found in both seminiferous tubules and epididymal ducts in agematched grt mice, though many degenerative germinal epitheliums were noted in the epididymis (Fig. 4B and 4D). The number of interstitial Leydig cells appeared less in grt mice than in normal mice at younger than 8 weeks of age (Fig. 5).

Our present results indicate that the reduced fertility of grt male mice during puberty may be associated with delayed onset of initial spermatogenesis. In fact, we showed that these mice need more than 13 weeks to develop mature testes. These findings are in accor-
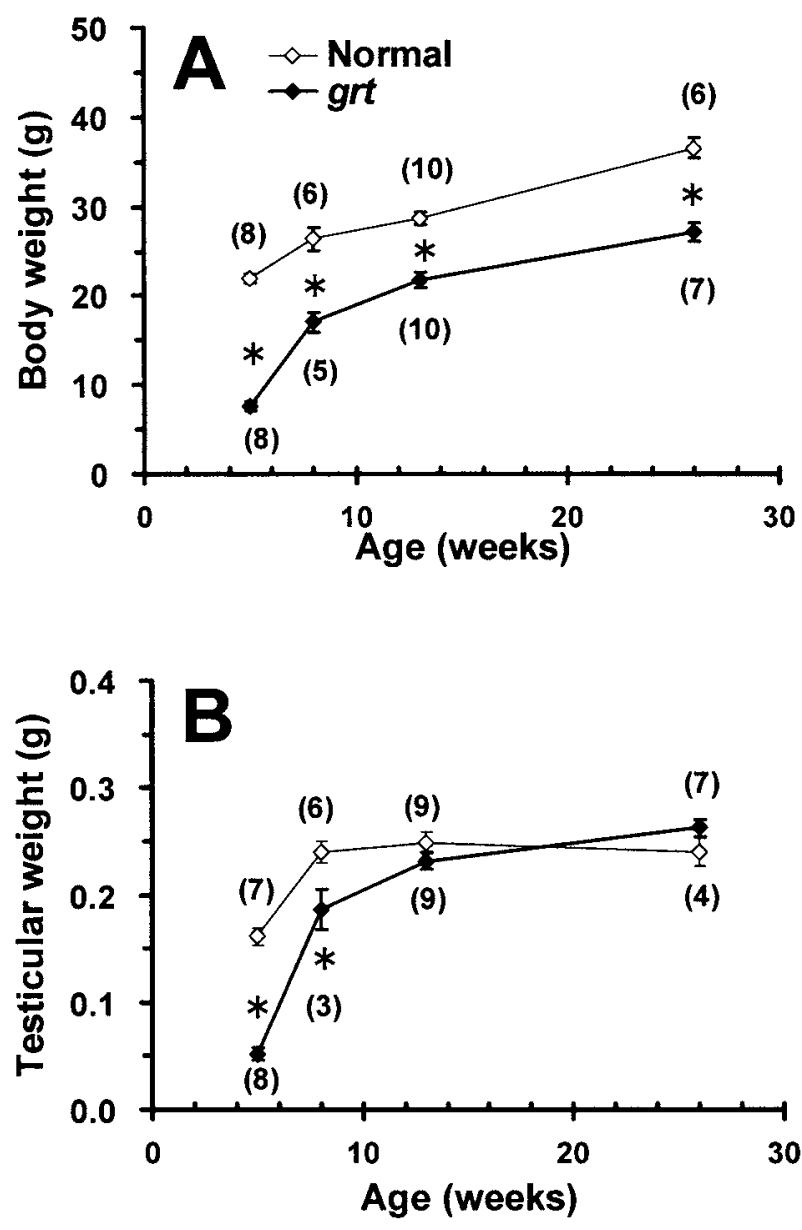

Fig. 1. Developmental changes in body weight (A) and testicular weight (B) in normal (open squares) and grt (closed squares) mice. Values are the mean $\pm \mathrm{SEM}$ of the number of mice shown in parentheses. *Significantly different from the corresponding normal mice $(P<0.05)$.

dance with a previous observation indicating a higher rate of occurrence of cytoplasmic droplets from caudal epithelial spermatozoa in $r d w$ rats [7]. These phenomena imply that grt mice might be delayed in the maturation and differentiation of sperm cells. Another report showed that hypothyroid rats exhibit underdeveloped epididymis resulting in impaired sperm motility [4]; therefore, we could not exclude the possibility that young grt mice might have underdeveloped epididymides.

The role of thyroid hormone in the development of reproductive organs is not well characterized. Based on our observations of the breeding process, grt mice have lower fertility at the young adult stage, but fertil- 

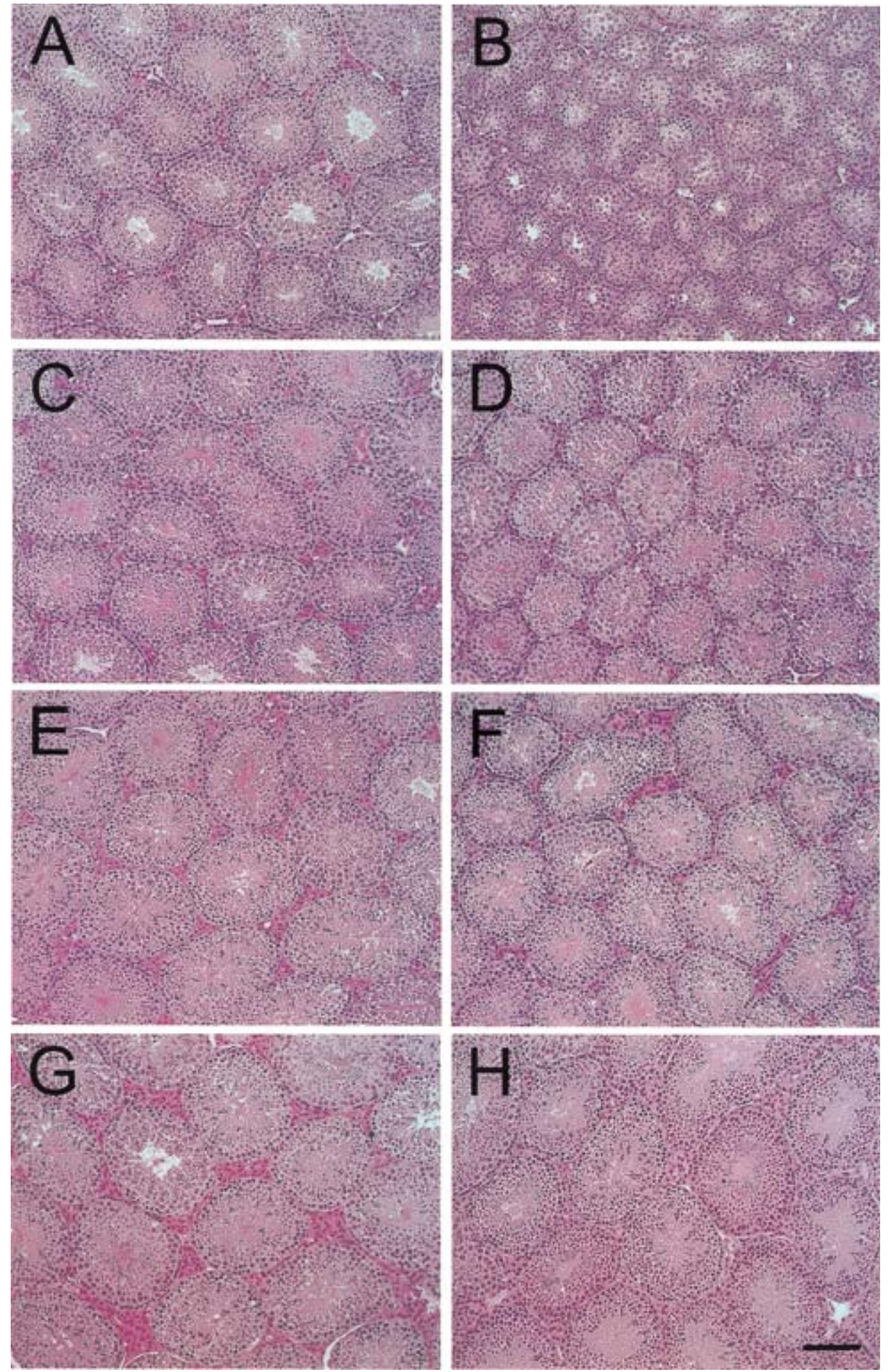

Fig. 2. Representative photomicrographs of the cross section of testes from normal (A, C, E, G) and $\operatorname{grt}(\mathrm{B}, \mathrm{D}, \mathrm{F}, \mathrm{H})$ mice at the ages of 5 weeks (A, B), 8 weeks (C, D), 13 weeks (E, F) and 26 weeks $(\mathrm{G}, \mathrm{H})$. The sections were stained with hematoxylin and eosin. Scale bar, $100 \mu \mathrm{m}$. 

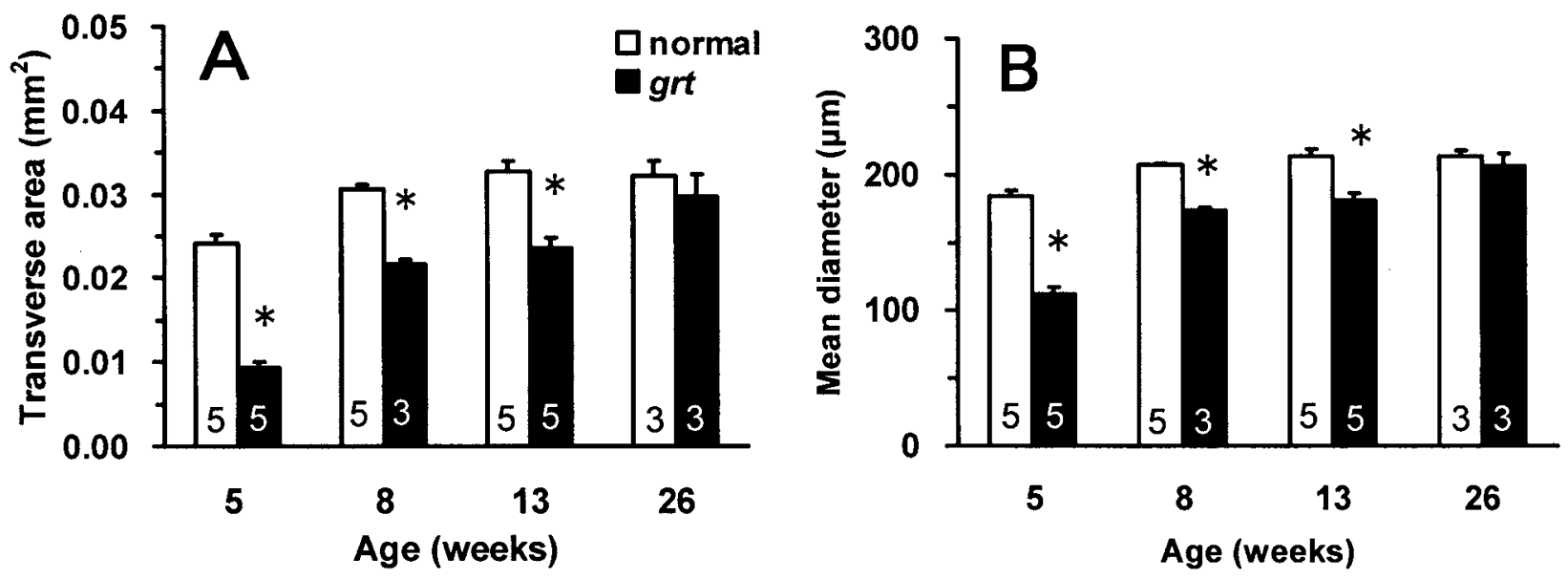

Fig. 3. Developmental changes in the transverse area (A) and mean diameter (B) of seminiferous tubules in normal and grt mice. Values are the mean \pm SEM of the number of mice shown in each column. *Significantly different from the corresponding normal mice $(P<0.05)$.

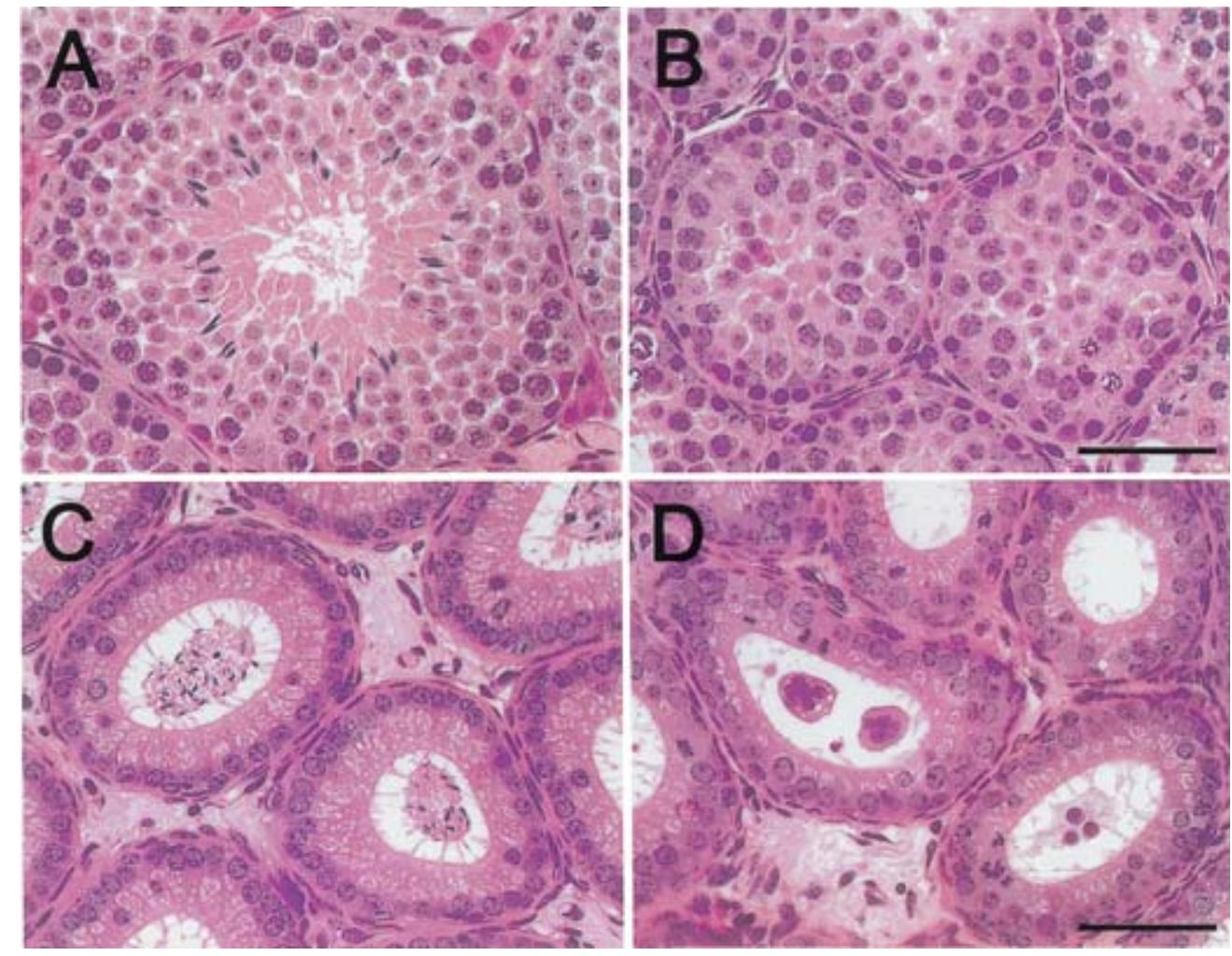

Fig. 4. Representative photomicrographs of the testes (A, B) and caput epididymides (C, D) in normal (A, $\mathrm{C})$ and $\operatorname{grt}(\mathrm{B}, \mathrm{D})$ mice. Images in $\mathrm{A}$ and $\mathrm{B}$ are enlargements of Figure $2 \mathrm{~A}$ and $2 \mathrm{~B}$, respectively. Scale bar, $50 \mu \mathrm{m}$.

ity is partially restored in grt mice after 6 months of age [8]. These findings are inconsistent with previous reports demonstrating that male hyt and $r d w$ rats are infertile throughout adulthood or not $[2,3,11,13]$. Despite the discrepancies between the present results and those from other studies reported by Umezu et al. 


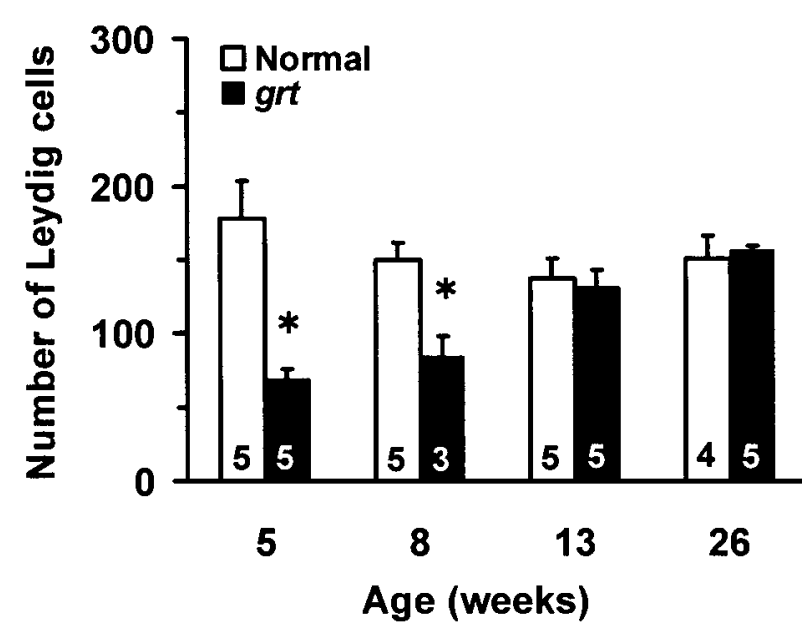

Fig. 5. Developmental changes in the number of Leydig cells in normal and grt mice. Values are the mean \pm SEM of the number of mice is shown in each column. *Significantly different from the corresponding normal mice $(P<0.05)$.

$[13,14]$, these model animals might highlight the important role of thyroid hormone in testicular development and function. We are currently unable to explain the partial restoration of fertility in the presence of a lifelong reduction in thyroid hormone levels [15] among some colonies of grt mice. It is also possible that several endocrine/paracrine factors may compensate for the reduced thyroid hormone level, allowing for the delayed testicular development [5].

The present histological study indicates that the reduced fertility of grt male mice during puberty might be associated with delayed onset of initial spermatogenesis. Further studies are in progress to elucidate the mechanisms that underlie the delayed testicular development in grt mice.

\section{Acknowledgment(s)}

The authors express their sincere thanks to Dr. M. Kusanagi (Japan Laboratory Animals, Inc., Japan) for establishing an SPF colony of DW/J mice. We also thank Professor T. Machida and Dr. T. Kobayashi (Department of Regulation Biology, Saitama University, Japan) for supplying DW/J mice.

\section{References}

1. Agui, T., Miyamoto, T., Tsumura, H., and Yoshida, T. 1997. Mamm. Genome 8: 944.

2. Beamer, W.J., Eicher, E.M., Maltais, L.J., and Southard, J.L. 1981. Science 212: 61-63.

3. Chubb, C. and Nolan, C. 1985. Endocrinology 117: 338346.

4. Del Rio, A.G., Blanco, A.M., Neipomnicze, H., Carizza, C., and Parera, F. 1998. Arch. Androl. 41: 23-26.

5. Hardy, M.P., Kirby, J.D., Hess, R.A., and Cooke, P.S. 1993. Endocrinology 132: 2417-2420.

6. Hayashi, T., Uchida, K., and Kawamoto, K. 2002. J. Exp. Zool. 292: 304-313.

7. Jiang, J.Y., Umezu, M., and Sato, E. 2000. Biol. Reprod. 63: 1637-1641.

8. Kobayashi, K., Kubota, H., and Saegusa, J. 2006. Proc. Jpn. Soc. Comp. Endocrinol. 21: 51.

9. Kobayashi, K., Sato, M., Machida, T., and Kobayashi, T. 2005. Congenit. Anom. (Kyoto) 45: 89-92.

10. Kobayashi, K., Yamamoto, H., Kobayashi, T., and Machida, T. 2001. Zoolog. Sci. 18: 955-961.

11. Koto, M., Sato, T., Okamoto, M., and Adachi, J. 1988. Exp. Anim. 37: 21-30.

12. Tomita, K., Yoshida, T., Morita, J., Atsumi, S., and Totsuka, T. 1995. J. Endocrinol. 144: 209-214.

13. Umezu, M., Kagabu, S., Jiang, J.Y., Niimura, S., and Sato, E. 2004. J. Reprod. Dev. 50: 675-684.

14. Umezu, M., Kagabu, S., and Sugawara, S. 1994. Exp. Anim. 43: 577-580.

15. Yoshida, T., Yamanaka, K., Atsumi, S., Tsumura, H., Sasaki, R., Tomita, K., Ishikawa, E., Ozawa, H., Watanabe, K., and Totsuka, T. 1994. J. Endocrinol. 142: 435-446. 